\begin{abstract}
This paper evaluates the factors that shape the establishment of transparent institutions in resource-rich countries with a specific focus on Kazakhstan. Specifically, it draws upon in-depth interviews and analysis of key institutions to understand the pace and intensity of transparency reforms in the Central Asian state. It argues that external transparency promotion can lead to institutional reform only when it is matched with strong elite incentives in favor of reforms. Kazakhstan has had few incentives to comply with Western-initiated norms before 2014, an era of relative economic security. As a consequence, the political elite often stalled the successful implementation of reforms. However, the economic turbulence following the fall of oil prices and Russia's annexation of Crimea has motivated the Kazakh government to embrace the norm of transparency in order to attract foreign investment.
\end{abstract}

Keywords: Transparency, governance, international institutions, democratization, oil revenues, Kazakhstan. 


\section{ELITE PREFERENCES AND TRANSPARENCY PROMOTION IN KAZAKHSTAN}

Transparency is a rational remedy to corruption in resource-rich countries as it allows citizens to monitor revenues from the sale of hydrocarbons and minerals. As such it can create public awareness and motivate responsible policies. International financial institutions (IFIs), multinational companies, and transnational advocacy networks (TANs) promote transparency in the extractive industries, meanwhile they expect developing resource-rich countries to comply with this norm. Yet, so strong is the appeal of absolute political control over hydrocarbons, in many resource abundant countries, concrete reforms towards more transparency are difficult to realize.

In this paper, I evaluate the factors that shape establishment of transparent institutions in hydrocarbon-rich countries with a specific focus on Kazakhstan. ${ }^{1}$ I argue that external transparency promotion facilitates institutional reforms only when it is matched with strong elite incentives in favor of reforms. These incentives are, in turn, determined by the relative economic security of the political elite. Prior to 2014, which corresponds to a period of relatively high commodity prices, Kazakhstan has had few incentives to comply with Western-initiated norms thanks to increasing revenues and a diversified composition of foreign direct investment. As a consequence, while external influences have helped to make natural resource management relatively more transparent, the lack of elite incentives limited the extent of reforms. However, since 2014, with the dramatic fall of oil prices and Russia's annexation of Crimea, Kazakhstan

\footnotetext{
${ }^{1}$ This paper draws upon in-depth interviews of the author with twenty government officials, non-governmental organization and representatives of international financial institutions in Kazakhstan conducted in June-July 2010. These interviews reveal the limitations of transparency promotion in Kazakhstan in this era.
} 
has now more incentives to address the issue of transparency, primarily in order to attract foreign investment from OECD countries.

The interaction between domestic and international spheres is key in understanding how external agents initiate overarching reforms in developing countries. Neglecting the contexts that influence elite preferences could severely undermine these efforts not only in the area of transparency, but also in human rights and environmental legislation. This paper proceeds as follows. I first present transparency as a potential remedy to the so called resource curse and lay out a framework that explains why some resource-rich countries might be more eager to adopt the norm of transparency. I then evaluate the particular interaction of transparency promotion and elite preferences in Kazakhstan that has contributed to the state of reforms in the country before and after the fall of oil prices.

\section{Transparency in resource-rich countries}

Abundance of natural resources, particularly hydrocarbons and minerals, puts a strain on the economic and political system of countries, a phenomenon often described as a "curse". In economic terms, resource dependency is associated with a lack of diversification and sluggish long-term growth; whereas the common political and institutional symptoms include rent seeking behavior and corruption (Anderson, 1987; Auty, 2001; Beblawi, 1987; Chaudhry, 1989; Karl, 1997; Larsen, 2004; Mahdavy, 1970; Mehlum, Moene, \& Torvik, 2008).

As the resource curse literature developed, an institutionalist perspective on the management of natural resources has become more prominent (Mehlum, Moene, \& Torvik, 2006). Rather than focusing on the mere existence of natural resources, an institutionalist focus 
problematizes the concepts of good governance and institutional quality as well as their roles in mitigating corruption and mismanagement in extractive industries. This emphasis on the quality of institutions assumes that rather than being an inevitable outcome, the so-called resource curse results from a government's inability or lack of intent to sustainably manage resource revenues (Atkinson \& Hamilton, 2003). Some examples of institutional qualities are the rule of law, accountability of government officials, freedom of speech, economic freedom, and transparency in government affairs (Krause, 2007).

Among these institutional qualities, transparency is arguably the most popular one since it is easier to implement compared to other aspects of good governance. Transparency acts as a precipitator that leads to better decisions, actions, and processes without intruding the political setting of a country (Kolstad \& Wiig, 2009, p. 529). With transparent institutions, decision makers are inclined to make choices that are acceptable by the population as a whole. This enables public involvement in policy making and helps citizens to hold officials accountable (Lindstedt \& Naurin, 2010).

Transparency in the extractive industries applies to the complete natural resource value chain, which includes the decision to extract, contracts, production data, revenues, and investments for sustainable development (NRGI, 2010). It often requires "a clear definition of goals, and rules-based operation; the public availability of information; and the adequacy of internal accounting and auditing of the funds; and arrangements for the appointment of officials and managers" (Kalyuzhnova, 2006, pp. 606-607). Governments that satisfy these conditions throughout the complete resource value chain could be considered as transparent.

Transparency as a norm in extractive industries emerged partly through the work of several TANs, such as Revenue Watch and Publish What You Pay (PWYP), which make a 
constant effort to highlight transparency as a remedy for extreme corruption and mismanagement in oil-rich countries. Similarly, IFIs, such as the World Bank and the International Monetary Fund (IMF) help redefine and standardize norms in order to improve the likelihood of their global adoption. For example, the IMF published its 'Guide on Resource Revenue Transparency' in 2007 as a measure to identify a set of best practices of revenue transparency (IMF, 2007, p. vii).

These transnational groups and financial institutions were also influential in the creation of the Extractive Industries Transparency Initiative (EITI), arguably the single most effective mechanism that addresses transparency in resource management. Established in 2003 by the initiative of the United Kingdom and several TANs, the EITI is a public-private partnership that includes supporters from a broad range of actors including states, businesses, and civil society groups. In the EITI framework, both participating governments and extractive companies publish their respective accounts meanwhile civil society groups monitor their progress. These accounts are eventually reconciled in yearly EITI reports, which are widely distributed and publicized (EITI, 2016b). As such, the EITI aims to diffuse the norm of transparency across developing resource-rich countries (EITI, 2016d). The following section analyzes mechanisms of norm diffusion that apply to extractive industries, focusing also on elite preferences.

\section{Transparency Promotion through Norm Diffusion and Elite Incentives}

Norms, such as transparency, are more specific than institutions and they single out certain types of behavior. Their promoters consider these norms appropriate and 'good', hence they recognize and appreciate actors who follow the norms, and disapprove and stigmatize those who break 
them (Finnemore \& Sikkink, 1998, p. 892). In that way, norms both constrain actors' behaviors and constitute their identities and interests (Checkel, 1997; Finnemore \& Sikkink, 1998). Here, I identify two mechanisms from the norm diffusion literature that contribute to institutional reform in resource-rich countries.

Firstly, as mentioned in the previous section, transnational ideational networks make an effort to spread the norm of transparency across borders. Since many resource-rich developing countries either lack the necessary capacity or the intention to adopt complete transparency in extractive industries, these external influences play a significant role. They specifically target political elites in order to transform their identities and goals. This process signifies the learning mechanism (Graham, Shipan, \& Volden, 2013), which implies that political leaders realize the potential benefits of transparency and internalize the norm. As such, an increase in the intensity of external influences from states, IFIs, and TANs is likely to facilitate the process of internalization of transparency in government bureaucracies.

Yet, at the same time, it is important that the political elite have material incentives in favor of transparency. In a globalized world, states often compete to make their institutions more hospitable to foreign capital (De Soysa \& Oneal, 1999; Elkins \& Simmons, 2004; Jensen, 2003). This mechanism of competition motivates states to adopt transparency as a norm in order to attract foreign investment, technical support, and international recognition, which can substantially increase the economic prospects of a country. These material incentives are extremely relevant for authoritarian resource-rich countries where the likelihood of a leader to stay in power is a direct function of their ability to maintain a source of income. Accordingly, if the political elite has serious concerns regarding the economic outlook of the country, they would be more inclined to embrace transparency in exchange for material benefits including 
foreign direct investments, improved bilateral relations with Western states and international firms, and increased access to supply chains. On the other hand, the relative economic security of the political elite would remove any incentives for reform.

\section{The Interaction}

It is crucial to define, explain, and understand the actual mechanisms and precise effects of external advocacy on the adoption of global norms. Despite their potential for stimulating reforms, external influences do not automatically induce institutional change (Goldsmith, 2008). Based on the theoretical arguments laid out above, I expect that in authoritarian hydrocarbon-rich countries, where the state enjoys financial autonomy from the societal forces, the adoption of international norms occurs through both elite learning and competition, the two key processes of norm diffusion (Checkel, 1997, p. 479). In other words, while external influences, such as TANs, IFIs, and Western governments help shape identities and initiate reforms, elite preferences, based on the relative economic security of the country, determine their extent and intensity. Consequently, when the preferences of elites and transparency promoters overlap, the chances of reform are much higher. The following sections focus on Kazakhstan as an energy-rich country and explain the nature of transparency promotion in the last decade based on the analytical framework explained above.

\section{Kazakhstan}

\section{An Overview of Institutions and Governance}

Kazakhstan is institutionally and economically the most developed Central Asian state and a major exporter of crude oil (EIA, 2016). Yet, the country also suffers from various problems of 
governance. Following its independence in 1991, the process of privatization opened up possibilities for those in high bureaucratic positions to channel significant sums to their offshore accounts. This period also saw numerous allegations of high-level corruption in extractive industries. According to an estimate, 20 percent of energy revenues were appropriated or misallocated since the independence (ICG, 2007, p. 24). Similarly, one study finds that only in 1996, Kazakhstan lost $\$ 500$ million to undisclosed transactions in the oil sector (Olcott, 2009, p. 160).

The president Nursultan Nazarbayev and his inner circle are immune from any investigation despite alleged corrupt activities directly linked to the highest positions in the government. The Kazakhgate affair is the biggest example of a high profile corruption case that remains unaddressed. In 2003, James Giffen, an American businessmen and an advisor of Nazarbayev, was charged in the United States with bribing top level Kazakh officials, including Nazarbayev himself, to help foreign oil companies sign lucrative deals (Dave, 2007, pp. 344345; Franke, Gawrich, \& Alakbarov, 2009, pp. 125-127). The case of Giffen is settled in court, and he pleaded guilty to proposed charges (Harper's, 2010), but there was never a formal investigation in Kazakhstan (Ostrowski, 2009, pp. 128-129). Today, Kazakhstan ranks among the most corrupt states in the world (World Bank, 2013), a fact that highlights the ongoing problem of governance and lack of transparency in the country (see Table 1). Below, I present the process of transparency promotion in Kazakhstan and the associated elite preferences before and after the fall of commodity prices in 2014 .

[Table 1 here] 


\section{External Influences and Diffusion of Transparency}

Since 1991, Kazakhstan has been eager to integrate into the international community as part of its multi-vector foreign policy, which emphasizes equal distance to all great powers. During the time of independence, President Nazarbayev wanted the country to join all international institutions it is eligible for, such as the World Bank, the IMF, the Asian Development Bank and the European Bank for Reconstruction and Development (Gleason, 2001, p. 171). These IFIs encouraged several institutional and political changes in Kazakhstan, which aimed to liberalize economic and political governance. For example, the government cut the number of presidential administration by fifty percent and reduced the number of ministers from twenty to fourteen in 1997 in response to the recommendations of the World Bank and the IMF (Cummings, 2005, p. 27).

The World Bank has probably been the most influential IFI in Kazakhstan and the efficiency of oil revenue management is an important component of its efforts in Kazakhstan. The Bank also provides technical assistance and prepares reports on the state of the industry; however, these reports are not made public unless the government approves. For example, when the World Bank wrote the "Economic Sector Analysis" for the Kazakh government in 2010 as part of the Joint Economic Research Program, this report was not disclosed in keeping with the wishes of the Kazakh government. ${ }^{2}$

Alongside the IFIs, TANs work closely with local groups to promote the transparency of oil revenues. Groups, such as the Open Society Institute, and the Revenue Watch began to

\footnotetext{
2 Interview with Lyaziza Sabyrova, Deputy Director, RAKURS Center for Economic Analysis, 23 June 2010 , Almaty. Interview with Elena Glinskaya, Program Leader, World Bank, 24 June 2010, Almaty.
} 
operate in the country since the 1990 s in order to make resource revenues more accessible to the people. Anton Artemyev, from the Soros Foundation, highlighted the importance of TANs working on revenue transparency in 2000s.

"Until a few years ago Soros Foundation only focused on education, health care, and arts. In 2002, there was an understanding that countries with high oil and gas revenues can have a huge potential for development. However, one has to make sure the revenues are managed transparently and accountably. So we restructured our administration, and we closed arts and culture. We established Kazakh Revenue Watch.” 3

The EITI is arguably the most important external influence on revenue transparency in Kazakhstan and this process was partly initiated by the work of IFIs and TANs. Kazakhstan expressed its desire to join the EITI as early as 2003 (PPRC, 2005a). However, unlike the neighboring Azerbaijan, which became a pilot case and a pioneer of transparency, Kazakhstan was reluctant to make rapid progress. Meruert Makhmutova claims that the first initiative to join the EITI came actually from non-governmental organizations (NGOs). ${ }^{4}$ In this period, NGOs, including the Soros Foundation, carried out numerous capacity building initiatives to establish a nationwide coalition and create watchdogs. ${ }^{5}$ Pavel Lobachev from the NGO "ECHO" explains their involvement in the EITI:

"In 2004, we created the coalition of NGOs for the EITI. It started with only fourteen NGOs, now we have sixty. We have representatives in fourteen regions and two cities. International institutions, including the World Bank, the British Council, and the Soros Foundation also helped the coalition as observers. Similarly, Publish What You Pay and Revenue Watch provided technical and financial assistance." 6

During the 2004 parliamentary and the 2005 presidential elections, this civil society coalition lobbied the president. Eventually, in June 2005, Nazarbayev personally announced his support for the EITI, which officially commenced the membership process (PPRC, 2005a, p. 14).

\footnotetext{
${ }^{3}$ Interview with Anton Artemyev, chair of the Executive Council, Soros Foundation-Kazakhstan, 02 July 2010 , Astana.

${ }^{4}$ Interview with Meruert Makhmutova, director, Public Policy Research Center, 21 June 2010, Almaty.

${ }^{5}$ Interview with Anton Artemyev, chair of the Executive Council, Soros Foundation-Kazakhstan, 02 July 2010 , Astana.

${ }^{6}$ Interview with Pavel Lobachev, Vice President, ECHO, 24 June 2010, Almaty.
} 
Beside the president, the World Bank also played a key role during the launching of the EITI process. Ilyas Sarsenov from the World Bank emphasized their participation during the early stages:

\begin{abstract}
"I was asked to launch the EITI a year after the president made the announcement. Though we were not part of the multi-stakeholder group, we spent a lot of time on the reporting process. Eventually, the Bank became the moderator; we try to facilitate the process. The government can overstretch during the whole process and they can pay less attention to the needs of the other parties. The Bank fills this gap." 7
\end{abstract}

Kazakhstan's EITI membership aimed to address problematic issues of governance related to revenue transparency, taxation of oil companies, and the general lack of knowledge on the oil fund. In order to join the initiative, Kazakhstan agreed to unilaterally disclose oil revenues from all enterprises in the oil and gas industry. The EITI membership also required oil companies to disclose their own tax payments and the Production Sharing Agreements (PSA) reports. The next section evaluates Kazakhstan's progress in making its extractive industries more transparent.

\title{
Evaluating Transparency in Extractive Industries
}

The majority of my interviewees in Kazakhstan agree on the deficiencies of the political regime with regards to transparency, especially on the public availability of information regarding government's revenues and expenditures. ${ }^{8}$ The lack of transparency is evident in the consolidation of reporting in the budget and other funds, the limited auditing capacity, and the lack of oversight on government's revenues and the tax expenditures (Tsalik, 2003, pp. 136-

\footnotetext{
${ }^{7}$ Interview with Ilyas Sarsenov, Senior Economist, World Bank, 30 June 2010, Astana.

${ }^{8}$ Interview with Dr. Altay Mussurov and Dr. John Dixon, KIMEP University, 22 June 2010, Almaty.
} 
138). The transparency of government revenues and the secret contracts with international oil companies are two key problems, which will be analyzed in detailed below.

\section{Government Revenues}

Kazakhstan created the National Oil Fund (NOF) against price fluctuations in 2000. By 2006, thanks to high production levels and prices, the fund had acquired $\$ 12$ billion from the sales of hydrocarbons. The official goal of the fund is to stabilize economic development, save for future generations, and reduce the country's dependency on price fluctuations (Tsalik, 2003, p. 146). Kazakhstan's constitution declares that all natural resources in the country belong to the state and people. However, the NOF's objectives were set by the president himself without public discussion (Karayianni, 2004, p. 152) and the Fund is regulated by presidential decrees. Janar Jandossova, the president of the research center, SANGE, is critical of the lack of public influence on the management of energy revenues:

In other countries they have taxes, but our money is alienated from us. It comes out of the blue. It is not clear that subsoil reserves belong to the people as mentioned in our constitution. The government is actually the only decision maker. In fact, all the resources belong to the government and people do not feel they own these resources. Even during the financial crisis, we did not feel this way. The government operates in complete secrecy and it is not accountable to the people.

The first major issue regarding the management of oil is the accounting of revenues that do not reach the fund. Certain practices, such as oil swaps with neighboring states, the export of oil to Russia below market prices, and oil sales to tax havens around the world, are carried out in secrecy (Tsalik, 2003, pp. 153-155). Elena Glinskaya, the World Bank's Human Development

\footnotetext{
9 Interview with Janar Jandossova, President, SANGE Research Center on Extractive Industries, 29 June 2010, Astana.
} 
Country Sector Coordinator in Kazakhstan, concedes that there is a lot of off-budget spending and that outsiders cannot exactly know the details of these transactions. ${ }^{10}$

The second major concern is the reporting process. The Ministry of Finance only selectively publishes the Fund's income and expenditure data. Consequently, documents of actual interest, such as the PSAs and Joint Venture Agreements with international oil companies remain undisclosed. Furthermore, the Ministry shares only the summaries of annual audit reports with the public rather than complete documents (Bacon \& Tordo, 2006, p. 88). The reports also lack a clear language for the general public (PPRC, 2005b, pp. 35-37).

The final issue is the undocumented spending of the NOF's revenues. The Law on the Oil Fund, which lays out the details of transfers to the government budget, was relaxed during the economic crisis. As a consequence, $\$ 10$ billion from the NOF were used to finance the anti-crisis measures and support the banks, but this "money did not come back". ${ }^{11}$ Transfers from the fund are usually aggregated with other budget transfers into one distinct account, which makes it almost impossible to process how the actual resource revenues are spent (Revenue Watch, 2010). In the end, while government's official revenues can be more or less estimated, the expenditures are essentially inaccessible. ${ }^{12}$

\footnotetext{
${ }^{10}$ Interview with Elena Glinskaya, Program Leader, World Bank, 24 June 2010, Almaty.

${ }^{11}$ Interview with Lyaziza Sabyrova, Deputy Director, RAKURS Center for Economic Analysis, 23 June 2010, Almaty.

${ }^{12}$ Interview with Pavel Lobachev, Vice President, ECHO, 24 June 2010, Almaty. Interview with Janar Jandossova, President, SANGE Research Center on Extractive Industries, 29 June 2010, Astana. Interview with Elena Glinskaya, Program Leader, World Bank, 24 June 2010, Almaty. Interview with Serikzhan Mambetalin, Leader, Kazakh Green Party, 25 June 2010, Almaty.
} 


\section{International Oil Companies}

The people of Kazakhstan also have a limited knowledge on the companies that are active in the resource sector including the details of their contracts and tax payments. This is mostly because a separate tax regime governs International Oil Companies (IOCs) in Kazakhstan. The terms of this regime include large upfront bonuses from the IOCs followed by lower taxes during the existence of the project. These measures protect the companies against tax fluctuations and instability. The downside is that the public cannot access these negotiated treaties. The companies' profits have traditionally been confidential and oil contracts have not been open to the public. ${ }^{13}$

The Kazakhgate affair clearly displayed the perils of clandestine business transactions and the secrecy surrounding the contracts reduces the credibility of officials involved in extractive industries (Luong \& Weinthal, 2010, p. 267). As such, many NGO representatives emphasize the need to make contracts transparent ${ }^{14}$ :

If we cannot understand contracts, we cannot estimate tax revenues and budget revenues. The government is protecting someone's interests by making contracts secret and it paints a gloomy picture of our economic system: non-open, non-transparent.". ${ }^{15}$

Another unusual issue regarding the IOCs in Kazakhstan has been their social spending obligations. The IOCs often allocate funds to regional administrators, who, in theory, use these funds for building and improving schools, hospitals, and other social projects. The regional governors have absolute control over these funds, and the lack of transparency often leads to allegations of corruption and mismanagement. There are clear signs that these funds are not used

\footnotetext{
${ }^{13}$ Interview with Meruert Makhmutova, director, Public Policy Research Center, 21 June 2010, Almaty. Interview with Pavel Lobachev, Vice President, ECHO, 24 June 2010, Almaty.

${ }^{14}$ Interview with Pavel Lobachev, Vice President, ECHO, 24 June 2010, Almaty.

${ }^{15}$ Interview with Meruert Makhmutova, director, Public Policy Research Center, 21 June 2010, Almaty.
} 
efficiently. For example, the oil-rich regions, or oblasts, such as Mangistau, Atyrau, and Kyzylorda, suffer more from income inequality and poverty compared to the rest of the country. Kyzlorda has the highest rate of infant mortality in all of Central Asia despite receiving major funds from IOCs on hospitals and clinics (Luong \& Weinthal, 2010, p. 278). Similarly, Atyrau is the richest oblast in the country in terms of per capita income, yet the region suffers from poverty rates of over 60 percent. Strikingly, 15 percent of the population in Atyrau does not have access to clean water. ${ }^{16}$

This section showed that despite the efforts of various external actors that promote good governance, in this period, Kazakhstan made limited progress in making natural resource management more transparent. Kazakhstan officially joined the EITI in 2005, however, for the next three years the country struggled to disclose revenues from foreign operators and the government prevented the participation of NGOs in the process (Öge, 2017). Kazakhstan eventually published its first EITI report in 2008 and became a compliant member only in 2013 (EITI, 2016a). Prior to 2014, the reports were published with significant lags and the participation of extractive companies was far from universal. Below I explain the underlying logic of transparency reforms in Kazakhstan in the decade preceding 2014. While external influences have been successful to instigate certain reforms, the relative economic security of the elite stalled further progress. Following this analysis, a brief section will evaluate Kazakhstan's transparency policy after 2014 in light of the steep fall in oil prices.

\footnotetext{
${ }^{16}$ Interview with Janar Jandossova, President, SANGE Research Center on Extractive Industries, 29 June 2010, Astana.
} 


\section{Elite Preferences in Kazakhstan}

In Kazakhstan, the centralized political system and lack of political accountability give the president and his close associates a clear mandate to control the hydrocarbons sector. As a consequence, citizens can neither access nor influence their government's policies meanwhile the parliament does not have an authority to monitor the management of extractive industries (Dave, 2007, pp. 344-345). In this context, material incentives of the political elite are essential in understanding transparency reforms in Kazakhstan.

As the biggest beneficiaries of the status quo, the natural tendency of the political elite would be to oppose transparency reforms proposed by IFIs and TANs. Yet, as the theoretical framework in this paper holds, short-term elite preferences on revenue transparency are heavily influenced by concerns over the economic security of the country. The more economically vulnerable a country is, the more likely that its leaders will actively support transparency reforms, especially if the economy relies on Western foreign investment.

\section{Economic Security}

The economic security of an energy-rich country is determined, above all, by production levels, global market prices, and its relative dependency on the particular resource. If a country has limited oil reserves, or expects a peak in oil production, the political leadership will be inclined to seek help from outsiders in the form of foreign direct investment and technology transfer in order to maintain the inflow of revenues. Similarly, a significant drop in the market price of the commodity is likely to have a comparable effect on elite preferences. In such contexts, 
implementation of transparency reforms is a useful signal to improve international prestige and attract foreign investment. In contrast, if a country has a secure revenue stream for the foreseeable future, the leadership will not be obliged to concede to the demands of IFIs, or the requirements of the EITI.

Kazakhstan's history of governance reforms does in fact correlate with the perceived economic security of the political elite. Astana was the most successful reformer in the postSoviet space during the 1990s when the country urgently required investment and aid from Western companies and IFIs in order to establish a sustainable infrastructure that can increase oil production. IOCs, including Chevron, ExxonMobil, BG Group, and ENI became major shareholders in Kazakhstan's biggest extraction projects. Yet, the persuasive powers of these external actors significantly diminished in 2000 s once the investments were made and the country achieved financial security thanks to high oil prices and the increase in production. In this period, Kazakhstan achieved a strong economic standing with 30 billion barrels of proven oil reserves, and became a major exporter of oil (EIA, 2016).

In early 2000s, the political elite and the public at large began to feel that the IOCs had taken advantage of the vulnerable position of the Kazakh government after independence. To address these concerns, the prime minister of the period, Imangaly Tasmagambetov, started renegotiating contracts in 2002, and he demanded informal concessions from the oil companies in the form of environmental regulations and taxes (Tsalik, 2003, pp. 136-138). In the end, while the government did not fully nationalize the oil industry, it revised the taxation system in order to expand the share of state-owned KazMunaiGas in existing and future projects. Kazakhstan also imposed "new royalties on extraction firms, limiting the application of tax stabilization 
agreements, raising export duties and heightening penalties for transfer pricing" (Kennedy \& Nurmakov, p. 3). These events underline the economic confidence of the Kazakh government and a shift in elite preferences away from an unquestioned accommodation of Western interests.

The second important indicator of economic security with regards to extractive industries is the dependency of the economy on oil revenues. By this criterion, the Kazakh elite has had some concerns. Between 2000 and 2007, almost half of Kazakhstan's exports have been hydrocarbons, and the ratio of hydrocarbons to total exports reached 59 percent in 2012 (CIA, 2012). The crude oil is the most important commodity and it will continue to dominate the economy for the next few decades. This was one of the key reasons Kazakhstan initially joined the EITI. At the same time, the country is less dependent on its oil revenues in comparison to its hydrocarbon producing neighbors, such as Azerbaijan and Turkmenistan (IMF, 2010). As the most stable country in the region with a generally reliable currency, Kazakhstan has attracted significant foreign investment to financial services, telecommunication, and construction sectors. Kazakhstan is also rich in minerals, including substantial reserves of copper, lead, and gold. While, the share of heavy industry and agriculture in the economy fell in the 2000 s due to increased oil production and high commodity prices, they are still important sources of economic activity (Olcott, 2007, pp. 5-6).

Overall, based on these indicators of economic security, one can conclude that in the period before 2014, the Kazakh elite was relatively secure in economic terms. Despite the dependence of the economy to oil exports, the government was not necessarily concerned about a potential decline in revenues. As such, transparency was only partially adopted and the EITI process was remarkably slow. 


\section{Elite Preferences since 2014}

Since 2014, the relative economic security of the Kazakh government was challenged on various accounts, which had a substantial impact on elite preferences on transparency reforms. Firstly, the fall in commodity prices, the devaluation of Tenge, and the decline in oil output have severely troubled the economic prospects of the country. In stark contrast to the prosperous 2000s where Kazakhstan had enjoyed the oil windfalls, the economic growth stalled to 1.2 percent in 2015 (World Bank, 2016). The extractive sector still contributes to more than 60 percent of the country's total exports, however, government revenues from the extractive industries declined from \$26 billion in 2014 to $\$ 12$ billion in 2015 (EITI Secretariat, 2016). In 2015, Kazakhstan announced a major privatization plan in order to address these economic problems. Astana is keen to invite European and American investors to participate in these plans, which include the sale of valuable state-owned assets including KazMunaiGas and the SamrukEnergy company (FT, 2015).

The second major factor that contributes to the economic insecurity of the political elite is Kazakhstan's complicated relationship with Russia in the last few years. Kazakhstan has always had close relations with Russia and Astana is a member of several Kremlin-led international organizations including the Collective Security Treaty Organization, the Eurasian Economic Union (EEU), and the Commonwealth of Independent States. Yet, despite these historically good relations between the two countries, Russia's annexation of Crimea in 2014 deeply concerns the Kazakh government. There is speculation both within Russia and Kazakhstan that a potential internal strife in Kazakhstan following Nazarbayev's eventual departure from office could give 
incentives to the Russian government to invade and annex North Kazakhstan, a region mostly populated by ethnic Russians (Stratfor, 2015).

In addition, deterioration of Russia's relations with the West and the economic embargo on Russia following its annexation of Crimea may have serious implications for the economy, especially given Kazakhstan's participation in the EEU. While Kazakhstan cannot afford to alienate Russia as a powerful neighbor and a trading partner, the government wants to reduce its economic dependence on Kremlin, which is seen as a liability. In a time of economic uncertainty, President Nazarbayev aims to maintain and increase economic relations with the West in order to restore the declining oil output and help stimulate the other sectors of the economy. To this end, in mining, the Kazakh government endorsed eleven current and foreseen projects with Western companies worth $\$ 72$ million (EITI Kazakhstan, 2015). Similarly, Nazarbayev had a meeting met with European Commission President Jean-Claude Juncker in March 2016 to strengthen economic and investment ties in the context of the EU's Enhanced Partnership and Cooperation Agreement with Kazakhstan (Kazinform, 2016).

Given these challenges to the political and economic security of the political elite and their interest in attracting more foreign investment from the OECD countries, it is not really surprising that Kazakhstan has made substantial progress towards transparency over the last three years. Since 2014, Kazakhstan has taken the lead in resource transparency in Eurasia and passed Azerbaijan as the pioneer of the EITI by producing reports significantly before their deadlines, which shows the eagerness of the Kazakhstani bureaucracy to comply with the norm of transparency. Kazakhstan also became the first ever EITI country to publish 2014 figures (EITI, 2016a), providing a very detailed overview of the natural resource sector in the country. 
Furthermore, the Kazakh government now requests companies to file their EITI reports online and publishes a simplified version of EITI reports on its website for the public at large (EITI, 2016c). In the past, Kazakhstan had been struggling to include all companies in the EITI process, but the most recent reports account for 99.55 percent of the revenues from the oil and gas sector and 98.82 percent of all revenues in the mining sector (EITI Kazakhstan, 2015).

Kazakhstan has also made substantial progress to disclose important data on social expenditures of IOCs, which are now "disaggregated by social programs, agreements, and constructed infrastructure sites" (EITI Secretariat, 2016). As such, these reforms address one of the key criticisms related to the tracking of these social payments at both state and local levels. Kazakhstan is also taking measures to amend legislation in order to allow beneficial ownership disclosure in extractive industries. These reforms will allow the public to identify individuals who profit from companies that operate in the country (EITI Kazakhstan, 2015; EITI Secretariat, 2016). Overall, while significant issues related to management of the oil fund and the contracts with international companies remain, the current trend towards more transparency is significant and likely to continue in the medium term given the economic insecurity of the political elite.

\section{Kazakhstan in Perspective}

Finally, it is essential to put the Kazakh experience in perspective in order to comprehend the interaction between transparency promotion and elite preferences that either facilitate or prevent institutional reforms. In the Caspian region, resource-rich Azerbaijan, Kazakhstan and Turkmenistan have comparable political and economic indicators. Nevertheless, in the last two decades, they have shown significant variation in terms of the transparency of oil and gas 
revenues. While Azerbaijan undertook substantial reforms from the outset to make its government revenues from oil transparent, in Kazakhstan transparency reforms progressed more slowly. Meanwhile, Turkmenistan refrained from disclosing its revenues from natural gas exports. Elite preferences explain this divergence of policies on transparency reforms. In Azerbaijan, the war with Armenia, heavy dependency on oil revenues, and the prominence of Western based IOCs, such as the British Petroleum, motivated both presidents, Heydar and Ilham Aliyev, towards fully endorsing the EITI (Öge, 2014). In contrast, in Turkmenistan, low levels of investment from the OECD states and Ashgabat's close relations with China and Russia rendered the necessity of transparency adoption obsolete (Öge, 2015). Finally, in Kazakhstan, as shown in this paper, the political elite has not been completely enthusiastic about making resource management transparent until the recent era of low oil prices.

\section{Conclusion}

Since its independence, Kazakhstan welcomed external influences that aim to improve governance of natural resources. Yet, until recently, despite a relatively committed civil society, the leadership of the country did not lend their resolute support to transparency promotion. The delay in Kazakhstan's compliance to the EITI membership in this period indicate that external transparency promotion is less effective when elite preferences, determined by structural indicators such as oil dependency and the composition of foreign direct investment, do not favor change. In particular, the economic security of the Kazakh elite reduced Kazakhstan's incentives to endorse reforms. 
This argument fills a major gap in the resource curse literature, as contemporary studies on resource dependency do not adequately address how institutions change in authoritarian contexts. In these countries, governance reforms are often shaped by an interaction between international and domestic factors, where external influences condition domestic agents to either initiate or intensify institutional reform. This interaction also has important implications for the broader field of democratization. Far reaching and sustainable reform initiatives towards further democracy require diffusion of norms through both incentives and ideational means, where institutional changes are adopted due to both external pressures and the preferences of the political elite. 


\section{TABLES}

Table 1 - Selected Economic and Political Indicators for Kazakhstan

\begin{tabular}{lc}
\hline & Kazakhstan \\
\hline Population & $17,289,224$ \\
GDP per capita (current US\$) & $14,310.00$ \\
Freedom Score 2014 & Not Free - 6 \\
Corruption Perceptions Index Ranking 2014 & $126 / 175$ \\
Fuel exports \% of merchandise exports & $82 \%$ \\
Extractive sector \% of fiscal revenues & $39 \%$ \\
Extractive sector \% of GDP & $33 \%$ \\
\hline
\end{tabular}

Notes: All the figures are for 2013 unless otherwise stated. Freedom Score is an index of political rights and civil liberties with 1 representing the most free and 7 the least free.

Sources: (CIA, 2014; Freedom House, 2015; Revenue Watch, 2013; Transparency International, 2014; World Bank, 2014a, 2014b) 


\section{BIBLIOGRAPHY}

Anderson, L. (1987). The state in the Middle East and North Africa. Comparative Politics, 20(1), $1-18$.

Atkinson, G, \& Hamilton, K. (2003). Savings, growth and the resource curse hypothesis. World Development, 31(11), 1793-1807.

Auty, RM. (2001). The political economy of resource-driven growth. European Economic Review, 45(4-6), 839-846.

Bacon, R., \& Tordo, S. . (2006). Experiences with Oil Funds: Institutional and Financial Aspects (Vol. 321/06): World Bank ESMAP.

Beblawi, Hazem. (1987). The Rentier State in the Arab World. In H. Beblawi \& G. Luciani (Eds.), The rentier state (pp. 49-62). New York: Croom Helm.

Chaudhry, K.A. (1989). The price of wealth: business and state in labor remittance and oil economies. International Organization, 101-145.

Checkel, J.T. (1997). International norms and domestic politics. European Journal of International Relations, 3(4), 473-495.

CIA. (2012). The World Factbook-Kazakhstan. Retrieved 09.05, 2012, from https://http://www.cia.gov/library/publications/the-world-factbook/geos/kz.html

CIA. (2014). The World Factbook. Retrieved 02/23, 2015, from https://http://www.cia.gov/library/publications/the-world-factbook/

Cummings, S.N. (2005). Kazakhstan: power and the elite. London and New York: IB Tauris.

Dave, B. (2007). Kazakhstan. In J. Goehring (Ed.), Nations in transit 2007: democratization from Central Europe to Eurasia (pp. 325-348). Hungary: Freedom House.

De Soysa, Indra, \& Oneal, John R. (1999). Boon or bane? Reassessing the productivity of foreign direct investment. American Sociological Review, 766-782.

EIA. (2016). Kazakhstan. Retrieved 01/18, 2016, from https://http://www.eia.gov/beta/international/analysis.cfm?iso=KAZ

EITI. (2016a). EITI Kazakhstan. Retrieved 08/11, 2016, from https://eiti.org/implementing_country/24

EITI. (2016b). How we work. Retrieved 08/17, 2016, from https://eiti.org/about/how-we-work

EITI. (2016c). Kazakhstan takes the lead on timely EITI reporting. Retrieved 08/11, 2016, from https://eiti.org/node/4445

EITI. (2016d). Who we are. Retrieved 08/17, 2016, from https://eiti.org/about/who-we-are

EITI Kazakhstan. (2015). 2015 National Report. Retrieved 01/19, 2016, from https://eiti.org/sites/default/files/documents/national_reports_fot_eiti_2015_eng.pdf

EITI Secretariat. (2016). Kazakhstan's 2015 EITI Report shows significant revenue drop. Retrieved 01/12, 2016, from https://eiti.org/news/kazakhstans-2015-eiti-report-showssignificant-revenue-drop

Elkins, Z., \& Simmons, B. (2004). The globalization of liberalization: Policy diffusion in the international political economy. American Political Science Review, 98, 171-190.

Finnemore, Martha, \& Sikkink, Kathryn. (1998). International norm dynamics and political change. International Organization, 52(04), 887-917.

Franke, Anja, Gawrich, Andrea, \& Alakbarov, Gurban. (2009). Kazakhstan and Azerbaijan as post-soviet rentier states: Resource incomes and autocracy as a double 'çurse' in postSoviet regimes. Europe-Asia Studies, 61(1), 109-140. 
Freedom House. (2015). Freedom in the World 2015. Retrieved 02/23, 2015, from https://freedomhouse.org/report/freedom-world/freedom-world-2015\#.VOteZ3 Y0fP4

FT. (2015). Crisis-hit Kazakhstan unveils ambitious privatisation plan. Retrieved 01/18, 2016, from https://http://www.ft.com/content/5b509962-824e-11e5-a01c-8650859a4767

Gleason, G. (2001). Foreign policy and domestic reform in Central Asia. Central Asian Survey, 20(2), 167-182.

Goldsmith, AA. (2008). Making the World Safe for Partial Democracy? Questioning the Premises of Democracy Promotion. International Security, 33(2), 120-147.

Graham, Erin R., Shipan, Charles R., \& Volden, Craig. (2013). The diffusion of policy diffusion research in political science. British Journal of Political Science, 43(03), 673-701.

Harper's. (2010). Kazakhgate Ends With a Whimper. Retrieved 03.14, 2012, from http://www.harpers.org/archive/2010/08/hbc-90007488

ICG. (2007). Central Asia's Energy Risks: International Crisis Group.

IMF. (2007). Guide on Resource Revenue Transparency. Retrieved 03/20, 2015, from https://http://www.imf.org/external/np/pp/2007/eng/101907g.pdf

IMF. (2010). Managing Natural Resource Wealth (Draft Program Document).

Jensen, Nathan M. (2003). Democratic governance and multinational corporations: Political regimes and inflows of foreign direct investment. International Organization, 57(03), 587-616.

Kalyuzhnova, Y. (2006). Overcoming the curse of hydrocarbon: Goals and governance in the oil funds of Kazakhstan and Azerbaijan. Comparative Economic Studies, 48(4), 583-613.

Karayianni, M. (2004). Product Sharing Agreements and National Oil Funds. In S. Akiner (Ed.), The Caspian: Politics, Energy and Security (pp. 147-154). New York: Routledge.

Karl, T.L. (1997). The paradox of plenty: Oil booms and petro-states. Berkeley and Los Angeles: University of California Press.

Kazinform. (2016). Kazakh President, European Commission President met in Hangzhou. Retrieved 01/18, 2016, from http://www.inform.kz/en/kazakh-president-europeancommission-president-met-in-hangzhou_a2945009

Kennedy, R., \& Nurmakov, A. (2010). Resource Nationalism Trends in Kazakhstan, 2004-2009.

Kolstad, Ivar, \& Wiig, Arne. (2009). Is transparency the key to reducing corruption in resourcerich countries? World Development, 37(3), 521-532.

Krause, M.E. (2007). Macroeconomic management for sustainable development: Experiences from Latin America. Paper presented at the National Conference on Zimbabwe's Economic Crisis: Towards a Lasting Solution, Harare.

Larsen, E.R. (2004). Escaping the resource curse and the Dutch Disease? When and why Norway caught up with and forged ahead of its neighbors. Discussion Papers.

Lindstedt, Catharina, \& Naurin, Daniel. (2010). Transparency is not Enough: Making Transparency Effective in Reducing Corruption. International Political Science Review, 31(3), 301-322.

Luong, P.J., \& Weinthal, E. (2010). Oil is not a curse: Ownership structure and institutions in soviet successor states. Cambridge: Cambridge University Press.

Mahdavy, Hossein. (1970). The patterns and problems of economic development in rentier states: the case of Iran. Studies in the Economic History of the Middle East, 428-467.

Mehlum, Halvor, Moene, Karl, \& Torvik, Ragnar. (2006). Institutions and the Resource Curse. The Economic Journal, 116(508), 1-20. 
Mehlum, Halvor, Moene, Karl, \& Torvik, Ragnar. (2008). Mineral rents and social development in Norway., Prepared for UNRISD project on Financing Social Policy in Mineral-Rich Countries. Geneva.

NRGI. (2010). The Value Chain. Retrieved 01/15, 2016, from http://www.resourcegovernance.org/analysis-tools/publications/value-chain

Öge, Kerem. (2014). The Limits of Transparency Promotion in Azerbaijan: External Remedies to 'Reverse the Curse'. Europe-Asia Studies, 66(9), 1482-1500.

Öge, Kerem. (2015). Geopolitics and revenue transparency in Turkmenistan and Azerbaijan. Eurasian Geography and Economics, 56(1), 89-110.

Öge, Kerem. (2017). Transparent autocracies: The extractive industries transparency initiative and civil society in authoritarian states. The Extractive Industries and Society.

Olcott, M.B. (2009). Kazakhstan: unfulfilled promise? Washington, D.C.: Carnegie Endowment for International Peace.

Ostrowski, W. (2009). Politics and oil in Kazakhstan. New York: Routledge.

PPRC. (2005a). Implementation of Extractive Industries Transparency Initiative in Kazakhstan: problems and prospects: Public Policy Research Center.

PPRC. (2005b). Oil Revenue Savings Funds: Experience of Alaska and Kazakhstan: Public Policy Research Center.

Revenue Watch. (2010). Countries. Retrieved 02.05, 2010, from http://www.revenuewatch.org/our-work/countries/index.php

Revenue Watch. (2013). Resource Governance Index. Retrieved 12/02, 2013, from http://www.revenuewatch.org/rgi

Stratfor. (2015). Blurring the Lines of Kazakhstan-Russia Relations.

Transparency International. (2014). Corruption Perceptions Index 2014. Retrieved 02/23, 2015, from http://www.transparency.org/cpi2014

Tsalik, S. (2003). Caspian oil windfalls: Who will benefit? New York: Open Society Institute, Central Eurasia Project.

World Bank. (2013). Worldwide Governance Indicators. Retrieved 08/28, 2014, from http://info.worldbank.org/governance/wgi/index.aspx - home

World Bank. (2014a). World Bank Group - Turkmenistan Partnership Snapshot. Retrieved $02 / 23,2015$, from http://www.worldbank.org/content/dam/Worldbank/document/TurkmenistanSnapshot.pdf

World Bank. (2014b). World Development Indicators. Retrieved 08/28, 2014, from http://wdi.worldbank.org

World Bank. (2016). Kazakhstan. Retrieved 01/18, 2016, from http://data.worldbank.org/country/kazakhstan 